University of Texas Rio Grande Valley

ScholarWorks @ UTRGV

$7-2008$

\title{
Dune and Vegetation Stability at South Padre Island, Texas, United States of America
}

Frank W. Judd

The University of Texas Rio Grande Valley

Kenneth R. Summy

The University of Texas Rio Grande Valley

Robert I. Lonard

The University of Texas Rio Grande Valley

Ruben A. Mazariegos

The University of Texas Rio Grande Valley

Follow this and additional works at: https://scholarworks.utrgv.edu/bio_fac

Part of the Biology Commons

\section{Recommended Citation}

Frank W. Judd, Kenneth R. Summy, Robert I. Lonard, Ruben Mazariegos; Dune and Vegetation Stability at South Padre Island, Texas, United States of America. Journal of Coastal Research 1 July 2008; 24 (4 (244)): 992-998. doi: https://doi.org/10.2112/07-0841.1

This Article is brought to you for free and open access by the College of Sciences at ScholarWorks @ UTRGV. It has been accepted for inclusion in Biology Faculty Publications and Presentations by an authorized administrator of ScholarWorks@ UTRGV. For more information, please contact justin.white@utrgv.edu,william.flores01@utrgv.edu. 


\title{
Dune and Vegetation Stability at South Padre Island, Texas, United States of America
}

\author{
Frank W. Judd ${ }^{\dagger}$, Kenneth R. Summy ${ }^{\dagger}$, Robert I. Lonard ${ }^{\dagger}$, and Ruben Mazariegos ${ }^{\ddagger}$ \\ ${ }^{+}$Department of Biology \\ The University of Texas-Pan American \\ Edinburg, TX 78541, U.S.A. \\ fjudd@utpa.edu \\ $\ddagger$ Department of Physics and Geology \\ The University of Texas-Pan American \\ Edinburg, TX 78541, U.S.A.
}

\begin{abstract}
JUDD, F.W.; SUMMY, K.R.; LONARD, R.I., and MAZARIEGOS, R., 2008. Dune and vegetation stability at South Padre Island, Texas, United States of America. Journal of Coastal Research, 24(4), 992-998. West Palm Beach (Florida), ISSN 0749-0208.

Padre Island is the longest of five barrier islands occurring along the Texas Gulf Coast. South Padre Island is separated from the northern two-thirds of the island by the Mansfield Channel. The composition and pattern of vegetation on South Padre Island are relatively well known, but data on the interrelationship of dune and vegetation stability are lacking. We hypothesized that (1) there should be an inverse relationship between elevation change and percent cover on transects across the nearshore dunes of South Padre Island; and (2) percent cover, species composition, and species importance should be most stable where elevation change was least. We tested these hypotheses using three study sites differing in vegetation abundance. Elevation measurements were taken at $1.0-\mathrm{m}$ intervals along three transects at each site using survey-grade Global Positioning System equipment. Vegetation abundance was determined in 10-m intervals along each transect. No sites or topographic zones were devoid of elevation change. Even a site that had a mean percent cover of $65.1 \%$ had a mean elevation change of $15.6 \mathrm{~cm}$. However, cover does not have to be great to provide considerable stability. There was no significant difference in elevation change at Site 1, where cover was $57 \%$, and Site 2 , where cover was only $12.5 \%$. As hypothesized, there was a significant inverse correlation between elevation change and percent cover when analyzed over all transects and sites, but the relationship did not hold for all sites or topographic zones when these were examined separately. Lack of correlation may be due to differences among sites and zones in the number of different perturbations and their intensities and frequencies. Only Site 2 showed a significant difference in percent cover between the initial and final samples. Species composition and importance were more stable where elevation changes were low.
\end{abstract}

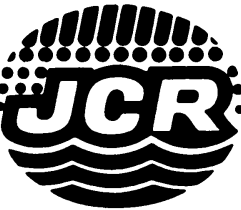

ADDITIONAL INDEX WORDS: Elevation change, percent cover, species importance.

\section{INTRODUCTION}

Padre Island is the longest of five barrier islands occurring along the Texas Gulf Coast. It extends $182 \mathrm{~km}$ southward from Corpus Christi to the Brazos Santiago Pass east of Port Isabel. South Padre Island is separated from the northern two-thirds of the island by the Mansfield Channel. It is 55 $\mathrm{km}$ long and has an area of about 16,200 ha (LONARD et al., 1999). The flora and vegetation of South Padre Island are relatively well known compared to other areas of the barrier island chain (DAHL et al., 1974; JUDD and LONARD, 1987; JUDD, LONARD, and SIDES, 1977; JUDD and SIDES, 1983; JUDD et al., 1989; LONARD and JUDD, 1980, 1997; LONARD,

\section{DOI: 10.2112/07-0841.1 received 4 March 2007; accepted in revision} 24 August 2007.

This study was supported in part by funds from the National Oceanic and Atmospheric Administration (NOAA) through a contract from the Coastal Coordination Council (Coastal Management Program) of the Texas General Land Office, Austin, Texas. Institutional matching funds were provided with the support of Dr. Edwin LeMaster, Dean, College of Science and Engineering, The University of Texas-Pan American. The views expressed herein are those of the authors and do not necessarily reflect the views of NOAA (or any of its sub-agencies), the Texas General Land Office, or The University of Texas-Pan American.
JUDD, and SIDES, 1978; LONARD et al., 1991; LONARD et al., 1999). Vegetation of the island differs from that of other barrier islands of the northern Gulf of Mexico and Atlantic coasts (JUDD, LONARD, and SidES, 1977; LONARD et al., 1999; STALTER, 1993). Except for scattered colonies of black mangrove (Avicennia germinans) near the southern end of the island, there are no shrub or tree zones present on South Padre Island. The vegetation is essentially one layered, and nearly all species are herbaceous perennials (JUDD, LONARD, and SiDES, 1977)

Vegetation pattern on South Padre Island is the result of a number of factors. Prevailing winds from the southeast laden with salt spray, periodic tropical storms, and hurricanes are important in determining species composition in the backshore and primary dune topographic facets (EHRENFELD, 1990; JUDD and SidEs, 1983; OOSTING and BILliNGS, 1942). Low annual precipitation accounts for the herbaceous and graminoid character of the vegetation in all topographic zones (LONARD et al., 1999). Other important factors are intense solar radiation, periodic droughts, nature of the soil and its water and salt content, level of the water table relative to the root zone, sand coverage, and human perturbations (JUDD and LONARD, 1987; JUDD, LONARD, and SIDES, 1977).

While the composition and pattern of the vegetation of 


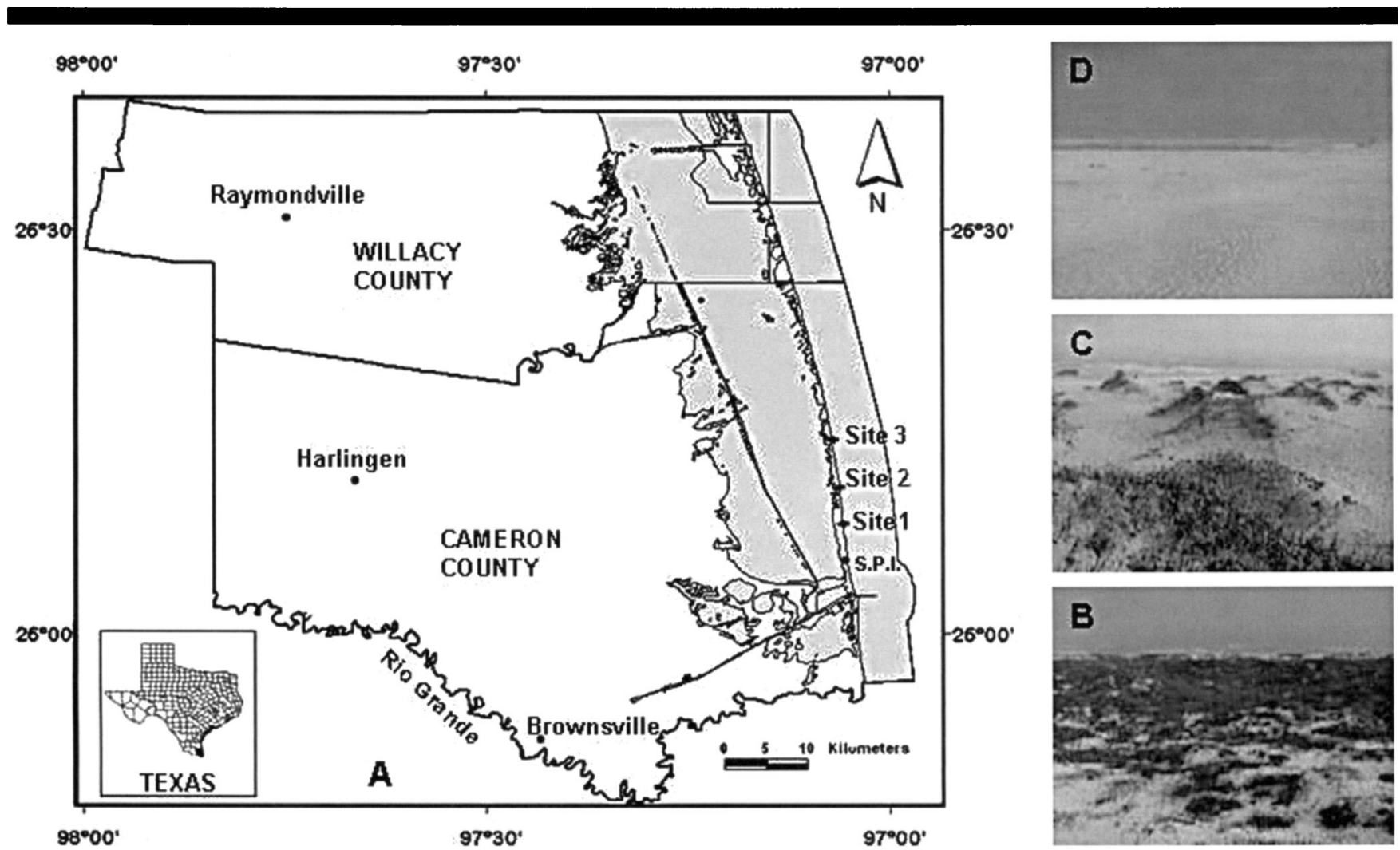

Figure 1. (A) Locations of study sites on South Padre Island (S.P.I.), Cameron County, Texas. Ground level photographs of the backshore zone (winter aspect) taken from atop primary dunes facing east at Site 1 (B), Site 2 (C), and Site 3 (D).

South Padre Island are relatively well known, little information is available on stability of the vegetation. Thus, while the immediate effects of a hurricane to nearshore vegetation and long-term (20 years) change in vegetation (LONARD et al., 1999) have been documented, the magnitude of change occurring on an annual basis is unknown, and the relationship between dune and vegetation stability has not been reported. Furthermore, there are no data available on the stability of dunes on South Padre Island.

That vegetation causes a deceleration of wind near to the surface (SARRE, 1989) is well established. This deceleration can cause aeolian transported sand to be deposited when vegetation is encountered, and vegetated surfaces can retard deflation. BUCKLEY (1987) reported that sand transport rates were negligible when vegetation cover was greater than $30 \%$, but WALKER et al. (2006) found that sand transport rates did not become negligible until vegetation cover was $60 \%$ or greater. Based on this information, we hypothesized that there should be an inverse relationship between elevation change and percent cover. Second, we hypothesized that vegetation should be most stable where elevation change was least (surface accumulating sand or losing sand). We tested these hypotheses using three study sites differing in vegetation abundance that extended from the Gulf of Mexico shoreline across the backshore and primary dune zones and into (at two sites) the secondary dune and vegetated flats zone.
This study also provides an assessment of how much vegetation is required to stabilize dune systems.

\section{METHODS}

Stability of dunes was assessed based on degree of elevation change at a site or topographic zone between the initial and final sampling dates. No change indicated a stable location, and sites or topographic zones with a smaller change in elevation were considered more stable than those with a greater elevation change. Stability of vegetation was evaluated in two ways: (1) degree of change in percent total cover; and (2) absence of change in important species, especially the dominant species, in the initial and final samples.

Based on ground observations and an aerial survey in June 2003 , we selected three study sites that appeared to differ markedly in vegetation abundance (Figure 1A). Site 1 was in a "dune protection zone" where vegetation appeared to be abundant and diverse (Figure 1B). This site was located about $400 \mathrm{~m}$ north of the South Padre Island Convention Center. It included a broad area of secondary dunes and vegetated flats zone. Site 2 was located $5 \mathrm{~km}$ north of Site 1 and appeared to have markedly less vegetation than Site 1 (Figure 1C). It included only a narrow strip of secondary dunes and vegetated flats zone. Site 3 was located near the northern end of Highway 100 where the roadway terminates abruptly. 
Table 1. Comparison of mean percent cover (live and standing dead veg etation in April 2005) and mean absolute elevation change (from March 2004 to May 2005) among study sites. $\mathrm{n}=$ number of 10-m intervals sam pled, $S D=$ standard deviation of the mean. Ten elevations were obtained within each 10-m interval. Means followed by different letters are different at the 0.05 level (Tukey-Kramer tests) or greater.

\begin{tabular}{ccrrrccc}
\hline \hline & & \multicolumn{2}{c}{ Cover } & & \multicolumn{2}{c}{ Absolute Elevation Change } \\
\cline { 3 - 4 } \cline { 6 - 7 } Site & $n$ & Mean \% & SD & & Mean (cm) & SD \\
\hline 1 & 82 & $57.0 \mathrm{a}$ & 26.28 & & $28.7 \mathrm{a}$ & 25.21 \\
2 & 48 & $12.5 \mathrm{~b}$ & 18.38 & & $31.1 \mathrm{a}$ & 31.52 \\
3 & 51 & $0.5 \mathrm{c}$ & 2.59 & & $71.9 \mathrm{~b}$ & 57.40 \\
\hline
\end{tabular}

There was very little vegetation present at this site (Figure $1 D$ ), and it had no secondary dunes or vegetated flats zone. Rather, the primary dune terminates at the shoulder of Highway 100.

At each of the sites, we established three parallel transects situated $25 \mathrm{~m}$ apart and extending $90^{\circ}$ east from the margin of Highway 100 to the high tide line of the Gulf of Mexico shore. To facilitate relocation of transects, the starting points at Highway 100 were recorded using a survey-grade Global Positioning System (GPS) unit (Trimble, Sunnyvale, California) and marked with orange paint. The transects at Sites 1 and 2 passed through four topographic zones (JUDD, LONARD, and SIDES, 1977): foreshore, backshore, primary dunes, and secondary dunes and vegetated flats. Transects at Site 3 did not include the secondary dunes and vegetated flats zone. The line-intercept method (CANFIELD, 1941) was used to quantify vegetation abundance and distribution. Each transect was divided into 10-m intervals, and data were recorded along the total length of each interval. First, we recorded the total cover of both live and standing dead vegetation intercepted by the line. Then each species intercepted by the line was rated individually and recorded without separation into strata. Frequency and foliage cover were recorded for each species, and from these data, relative frequency, relative cover, and an importance value that was the sum of relative frequency and relative cover were calculated. Importance values were used to determine dominance. The topographic zone that each interval occurred in was also recorded. Vegetation was sampled at two periods: from 30 May 2004 to 5 June 2004, and from 6 April 2005 to 9 April 2005.

Elevation measurements were taken at $1.0-\mathrm{m}$ intervals along each transect using dual frequency (survey-grade) GPS equipment, which included a Trimble $5700^{\circledR}$ base station, one or more Trimble $5800^{\circledR}$ rover receivers, and Trimble Trimark III ${ }^{\circledR}$ radio transmitters. Prior to conducting elevation surveys, we established a control network of four sites by conducting 2-hour static measurements followed by a site calibration. These benchmarks were used to conduct real-time kinematic surveys, which provide a potential accuracy of 5.0 $\mathrm{mm} \pm 1 \mu \mathrm{m}$ for two-dimensional coordinates and $\pm 1.0 \mathrm{~cm}$ for elevation measurements. In most cases, the base station was installed on the benchmark near Site 2, and a "repeater" radio unit was used to transmit signals to rover units operating at each of the three study sites. Elevation was measured at the same dates that vegetation sampling occurred. At each sample point, the elevation change occurring between the ini-
Table 2. Comparison of mean percent cover (live and standing dead vegetation in April 2005) and mean absolute elevation change (from March 2004 to May 2005) among topographic zones (sites combined). $\mathrm{n}=$ number of 10-m intervals sampled, $S D=$ standard deviation of the mean. Ten elevations were obtained within each 10-m interval. Means followed by different letters are different at the 0.05 level (Tukey-Kramer tests) or greater.

\begin{tabular}{lcccccc}
\hline \hline & & \multicolumn{2}{c}{ Cover } & & \multicolumn{2}{c}{ Absolute Elevation Change } \\
\cline { 3 - 4 } \cline { 7 - 7 } Topographic Zone & $n$ & Mean \% & SD & & Mean $(\mathrm{cm})$ & SD \\
\hline Backshore & 82 & $24.2 \mathrm{a}$ & 32.06 & & $33.8 \mathrm{a}$ & 21.62 \\
$\begin{array}{l}\text { Primary dunes } \\
\text { Secondary dunes }\end{array}$ & 67 & $17.9 \mathrm{a}$ & 23.18 & & $63.4 \mathrm{~b}$ & 58.63 \\
$\begin{array}{l}\text { and vegetated } \\
\text { flats }\end{array}$ & & & & & & \\
\hline
\end{tabular}

tial and final samples was calculated as $\Delta_{e}=E_{I+1}-E_{I}$, where $\Delta_{e}$ represents the signed difference between the elevations (in $\mathrm{m}$ ) measured at that point on the final sample date $\left(\mathrm{E}_{\mathrm{I}+1}\right)$ relative to the initial sample date $\left(\mathrm{E}_{\mathrm{I}}\right)$. Using this procedure, positive values of $\Delta_{e}$ indicated elevation increases, negative values indicated elevation decreases, and values approaching zero were indicative of no elevation change.

Because vegetation abundance was recorded at $10-\mathrm{m}$ intervals and elevation was recorded at $1.0-\mathrm{m}$ intervals, we calculated the mean absolute elevation change occurring within each 10-m interval for use in correlation analyses of percent cover and absolute elevation change. We used the data on vegetation abundance in April 2005 for comparison with absolute elevation change occurring between the initial and final elevation surveys.

\section{RESULTS}

As seen in Table 1, there was significant variation in percent cover among the sites $(F=146.6,2,178 \mathrm{DF}, p<0.001)$, and Tukey-Kramer tests revealed that Site 1 had significantly greater cover than either Site $2(p<0.01)$ or Site $3(p$ $<0.01$ ). Cover also was significantly greater at Site 2 than at Site $3(p<0.05)$. Species richness was greater where cover was greater, i.e., there were 41 species at Site 1,15 species at Site 2 , and only 4 species at Site 3 .

Table 1 also shows that comparison of mean absolute (unsigned) elevation change varied significantly among study sites $(F=22.209,2,178 \mathrm{DF}, p<0.001)$. Despite the significant difference in percent cover at Sites 1 and 2, there was no significant difference in mean elevation change between the two sites. Mean elevation change at Site 3 (where cover was only $0.5 \%$ ) was significantly greater than at both Sites 1 and 2 (Tukey-Kramer tests, $p<0.01$ ).

Table 2 shows that percent cover (sites and transects combined) varied significantly among the topographic zones ( $F=$ $32.890,2,178 \mathrm{DF}, p<0.001$ ). Tukey-Kramer tests revealed that the variation was due to cover being greater in the secondary dunes and vegetated flats zone than in either the backshore $(p<0.01)$ or primary dune zone $(p<0.01)$. As predicted, elevation change was greatest in the topographic zone where cover was least and least in the zone where cover was greatest. Tukey-Kramer tests showed that elevation change was significantly greater in the primary dune zone than either the backshore $(p<0.01)$ or secondary dunes and 
All Sites and Transects

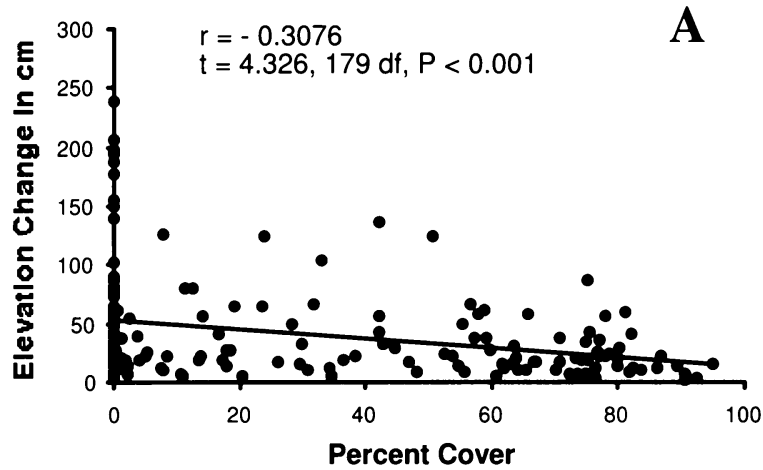

Primary Dunes

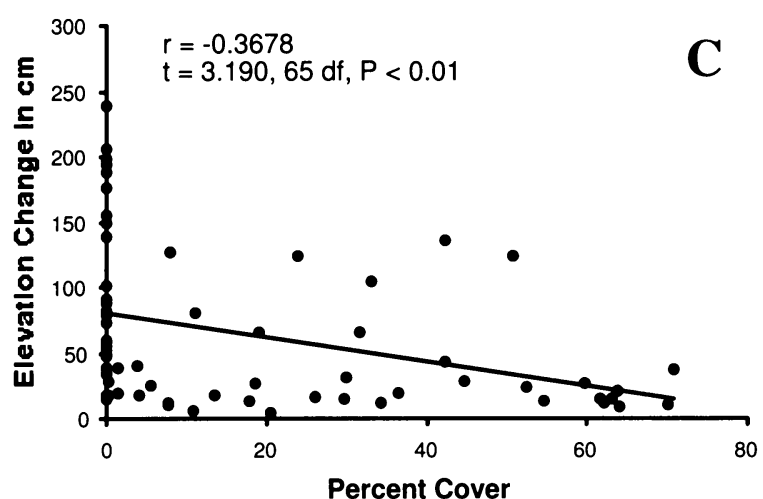

Site 1

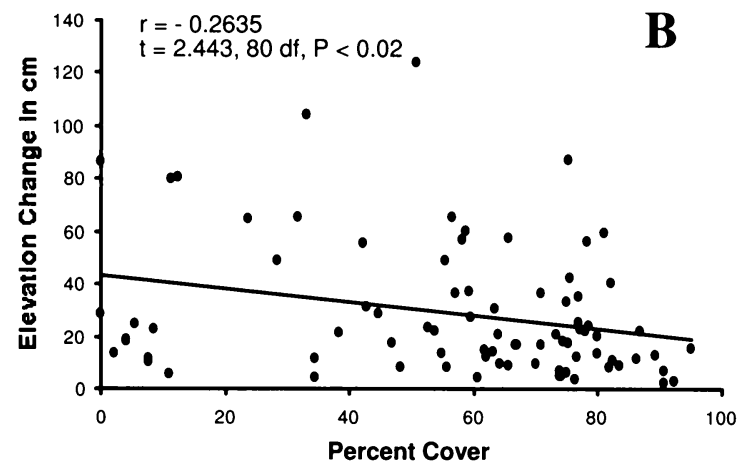

Secondary Dunes and Vegetated Flats

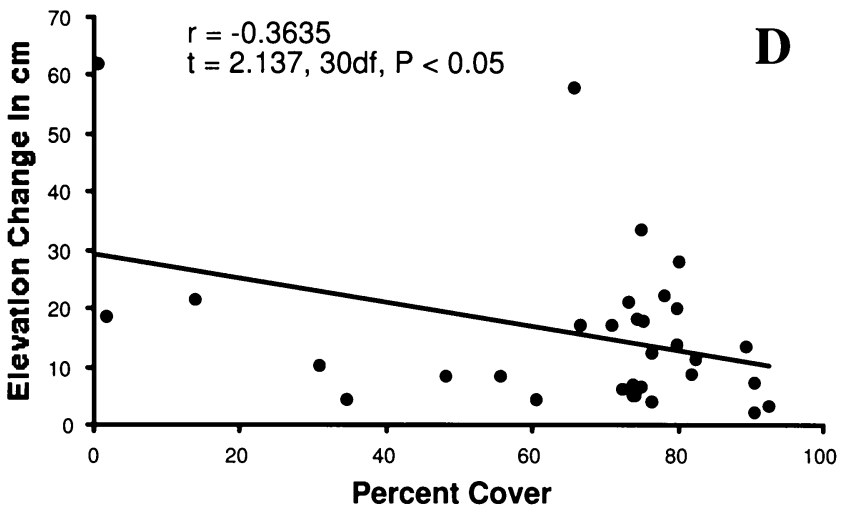

Figure 2. Correlation between elevation change and percent total vegetative cover for (A) three study sites combined, (B) Site 1, (C) primary dune topographic zone for three sites combined, and (D) secondary dunes and vegetated flats topographic zone for Sites 1 and 2 combined.

vegetated flats zones $(p<0.01)$. There was no significant difference in elevation change of the backshore and secondary dunes and vegetated flats zones $(p>0.05)$.

As predicted, there was a significant inverse correlation between absolute elevation change and percent cover (Figure 2A) when cover and elevation change were analyzed over all transects and sites. However, the correlation was relatively weak. Examination of the relationship between cover and elevation change separately by sites shows that there was a

Table 3. Comparison of percent cover at the initial and final vegetation sampling dates among study sites. $\mathrm{n}=$ number of 10-m intervals sampled, $S D=$ standard deviation of the mean.

\begin{tabular}{ccccccc}
\hline \hline Site & Date & $n$ & Mean & SD & $t$-value & Probability \\
\hline 1 & May 2004 & 82 & 59.7 & 23.31 & \multirow{2}{*}{0.615} & $p>0.5$ \\
1 & April 2005 & 82 & 57.5 & 22.69 & & \\
2 & June 2004 & 48 & 18.9 & 12.66 & 2.492 & $p<0.02$ \\
2 & April 2005 & 48 & 12.5 & 12.54 & & \\
3 & June 2004 & 51 & 0.3 & 0.46 & 1.017 & $p>0.2$ \\
3 & April 2005 & 51 & 0.5 & 0.97 & & \\
\hline
\end{tabular}

weak but significant inverse correlation at Site 1 (Figure 2B). There was no significant correlation between cover and elevation change at Site $2(r=0.1230 ; t=0.841,46 \mathrm{DF}, p>$ $0.4)$ or Site $3(r=-0.1450 ; t=0.141,49 \mathrm{DF}, p>0.5)$. There was so little vegetation present at Site 3 that it is not surprising that there was no correlation. Only 3 of the 51 intervals had vegetation present. At Site 2, only 2 of the 48 intervals sampled had cover values greater than $42 \%$. Thus, cover may not have been great enough at most intervals to hold elevation change in check.

The correlation between percent cover and absolute elevation change in the backshore zone (all sites and transects combined) was not significant ( $r=0.0649 ; t=0.582,80 \mathrm{DF}$, $p>0.5$ ), but there was a significant inverse correlation in the primary dunes (Figure 2C) and secondary dunes and vegetated flats (Figure 2D). Only Site 2 showed a significant difference in cover between sampling dates (Table $3 ; t=2.492$, $94 \mathrm{DF}, p<0.02$ ). Site 2 was not the site with the least cover or the greatest change in elevation.

In the backshore zone at Site 1, Heterotheca subaxillaris was the dominant species at both sampling dates, and four 
Table 4. Comparison of species importance among topographic zones at Site 1 at the initial and final sampling dates. Only species ranking 1 through 5 in importance are compared. Imp. Value = importance value (the sum of relative frequency and relative cover), SDVF = Secondary Dunes and Vegetated Flats.

\begin{tabular}{lcc}
\hline \hline \multicolumn{1}{c}{ Species } & Imp. Value & Species \\
\hline Backshore, May 2004 & & Backshore, April 2005 \\
Heterotheca subaxillaris & 74.6 & Heterotheca subaxillaris \\
Uniola paniculata & 25.6 & Uniola paniculata \\
Oenothera drummondii & 22.5 & Chamaecrista fasciculata \\
Chamaecrista fasciculata & 18.7 & Oenothera drummondii \\
Indigofera miniata & 17.9 & Ipomoea pes-caprae \\
Primary Dunes, May 2004 & & Primary Dunes, April 2005 \\
Heterotheca subaxillaris & 69.4 & Heterotheca subaxillaris \\
Chamaecrista fasciculata & 48.8 & Chamaecrista fasciculata \\
Uniola paniculata & 36.5 & Uniola paniculata \\
Croton punctatus & 7.8 & Schizachyrium littorale \\
Indigofera miniata & 6.7 & Croton punctatus \\
SDVF, May 2004 & & SDVF, April 2005 \\
Paspalum monostachyum & 40.6 & Schizachyrium littorale \\
Heterotheca subaxillaris & 36.4 & Heterotheca subaxillaris \\
Schizachyrium littorale & 34.7 & Paspalum monostachyum \\
Uniola paniculata & 22.0 & Uniola paniculata \\
Indigofera miniata & 12.1 & Galactia canescens \\
\hline
\end{tabular}

of the five most important species were the same at both dates (Table 4). In May 2004 the five most important species contributed $79.7 \%$ of the overall importance. In April 2005 the five most important species contributed $81.4 \%$ of the overall importance.

The same relationship held in the primary dune zone at Site 1 (Table 4). H. subaxillaris was a clear dominant, and four of the five most important species were the same at both the initial and final sampling dates. The five most important species contributed $84.6 \%$ of the total importance in 2004 and $87.6 \%$ of the total importance in 2005.

The secondary dunes and vegetated flats zone at Site 1 also had four of the five most important species in common at the two sampling dates (Table 4). However, there were different dominant species in 2004 and 2005. Paspalum monostachyum was the dominant in 2004, and Schizachyrium littorale was the dominant in 2005. The change in dominant species is not a great shift in importance because there is only a $5.9 \%$ difference in importance of the species ranked first and third in 2004 and an $8.9 \%$ difference in importance of the first and third species in 2005. The shift in importance of $S$. littorale from 2004 to 2005 was only $14 \%$. Thus, there was little difference in importance of species ranking first, second, and third at either the initial or final sampling dates.

There were only three species present in the backshore zone at Site 2 in June 2004 and only two species present in April 2005, but there was a great difference in species importance at the two sampling dates (Table 5). In June 2004 Ipomoea pes-caprae was a clear dominant, but in April 2005 Croton punctatus and I. pes-caprae were of almost equal importance, i.e., they were co-dominants.

In the primary dunes at Site 2 , the same five species were the five most important species at the two dates, but their importance differed markedly (Table 5). One point of similarity is that $I$. pes-caprae and $C$. punctatus were the two most important species at the two dates. In the secondary dunes and vegetated flats zone at Site 2 , four of the five most im- portant species were common to the two sampling dates, but there was a major difference in the dominant species. Chamaecrista fasciculata was the dominant species in June 2004, but it was not among the five most important species in April 2005. The species ranking third, fourth, and fifth had the same ranking at the two sampling dates.

At Site 3, vegetation was present only in the backshore zone (Table 5). Only two species were present at each sampling date, and only one species, I. pes-caprae, was common to both dates.

\section{DISCUSSION}

The effect of plant cover on transport of dune sand is an important factor in sand stabilization, rehabilitation, and restoration ecology (BUCKLEY, 1987). The rate of sand transport and dune migration are considerable on Padre Island. WEISE and WHITE (1980) reported that the average rate of dune migration in a back-island dune on North Padre Island was $10.7 \mathrm{~m}$ per year northwestward. In wind tunnel experiments, BUCKLEY (1987) showed that, at a plant cover of $17 \%$ and wind velocity of $10 \mathrm{~m} / \mathrm{s}$, sand transport was only $16 \%$ of the transport over bare sand. At a wind velocity of $15 \mathrm{~m} / \mathrm{s}$, sand transport was $22 \%$ of the transport over bare sand. Plant cover greater than $17 \%$ was not tested, but extrapolations of the effect showed that sand transport became zero at a cover of $37 \%$ and a wind velocity of $10 \mathrm{~m} / \mathrm{s}$. In contrast, NoRDsTROM et al. (2006) found that, in nature, appreciable localized transport occurred where vegetation cover was $50 \%$ and sand transport rates did not become negligible until cover reached $60 \%$. Our data are consistent with these findings. There was no significant difference in elevation change between Site 1 , where mean cover was $57 \%$, and Site 2 , where mean cover was only $12.5 \%$. Thus, cover does not have to be great to reduce sand transport and elevation change. This finding has important implications for dune stabilization projects. It also is important to note that no sites or topographic zones on 
Table 5. Comparison of species importance among topographic zones at the initial and final sampling dates at Sites 2 and 3 . If more than five species were present, only the top five species in importance are shown. Imp. Value = importance value (the sum of relative frequency and relative cover), SDVF $=$ Secondary Dunes and Vegetated Flats.

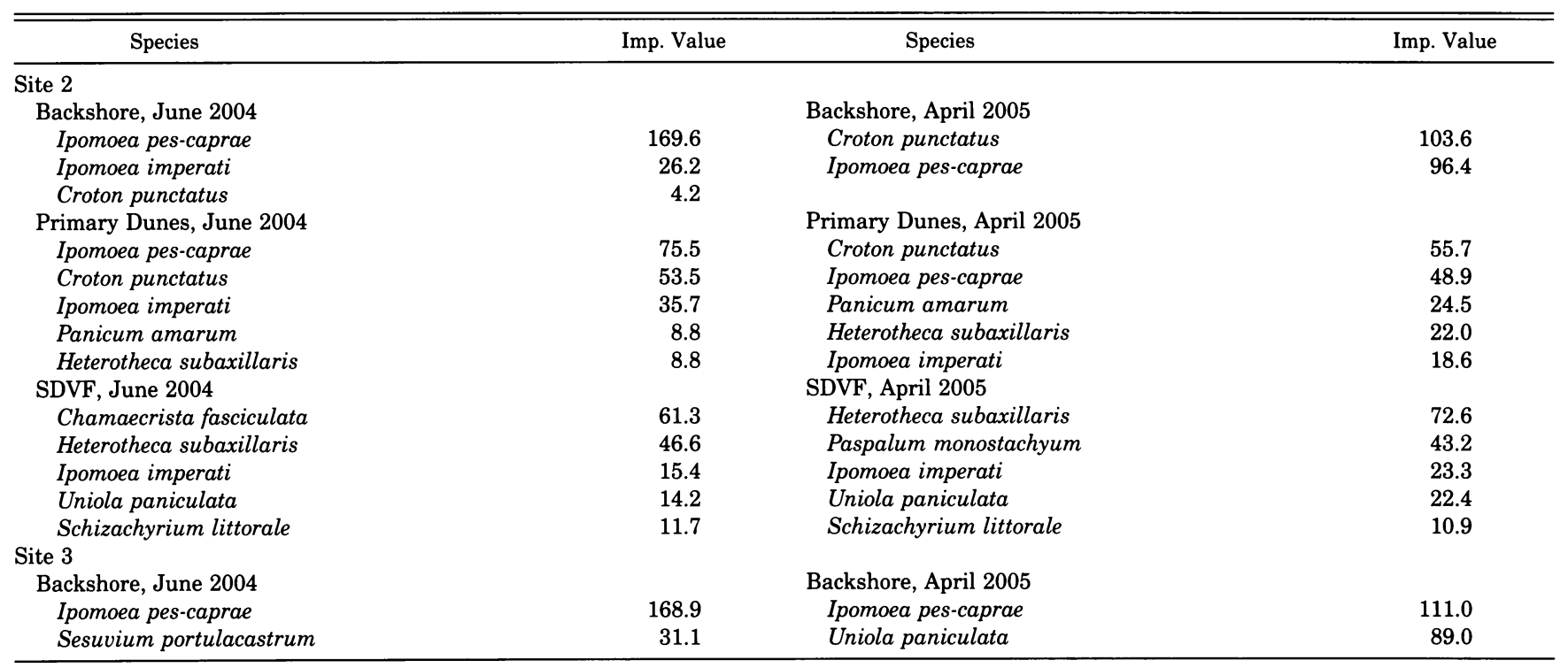

South Padre Island were devoid of elevation change. Mean elevation change was still considerable $(15.6 \mathrm{~cm})$ where mean percent cover was as great as $65.1 \%$. EHRENFELD (1990) reports that the net change of sand on barrier island foredunes usually is about 10 to $50 \mathrm{~cm}$ per year (erosion or accretion).

Our first hypothesis, that there should be an inverse relationship between elevation change and percent cover, was confirmed when all sites and transects were combined, but the relationship did not hold at all sites or in all topographic zones. For a correlation analysis to show a significant inverse relationship, the distribution of vegetation must be greater than some minimal quantity-e.g., in the case of Site 3, more than in 3 of 51 intervals (5.9\%). In addition, there must be sufficient vegetative cover at some locations within a site to hold sand in place. Absence of the latter criterion may have caused the lack of correlation between elevation change and percent cover at Site 2 . However, neither of these two factors explains the lack of correlation between percent cover and elevation change in the backshore zone (all sites combined). Fifty of the 80 intervals sampled had vegetation present, and percent cover ranged from 0 to $95 \%$.

The backshore zone is subject to more perturbations than the primary dunes and secondary dunes and vegetated flats zones (JUDD and SidEs, 1983). At Sites 2 and 3 this zone was exposed to vehicular traffic, trampling by humans, and storm tides that did not reach the primary dunes or the secondary dunes and vegetated flats. In addition, wind velocity from the prevailing onshore winds in the backshore is greater than on the lee side of the primary dunes or in the secondary dunes and vegetated flats. Perhaps the perturbations (especially vehicular traffic) decrease the effectiveness of vegetation as a sand binder in this zone, so that sand losses and gains are frequent regardless of the percent cover. For example, the backshore is the zone where aeolian transported sand from the foreshore zone first begins to be stopped by vegetation and accumulates in foredunes. Likewise, sand loss occurs in all parts of the zone (areas with vegetation and areas without) as the prevailing southeasterly winds move sand westward to the primary dune zone. In contrast, elevation change in the secondary dunes and vegetated flats is primarily by sand gain from sand transported into the zone by wind from the primary dunes. Sand loss is mostly limited to the areas with little or no vegetation, and the more vegetation, the less loss occurs, at least until some threshold of cover is reached.

Despite the greater perturbations in the backshore zone, the primary dune zone had significantly greater elevation change than either the backshore or secondary dune and vegetated flats zones. This was no doubt due to the total absence of vegetation on the primary dunes at Site 3 . Here there was no vegetation to impede sand transport.

Our second hypothesis, that vegetation should be most stable where elevation change was least, was not supported for stability of percent cover or stability of species composition and importance. This was due to the extremely low quantity of vegetation at Site 3 . For example, there could be little change in percent cover at this site even if all vegetation was lost. If one compares the stability of percent cover or stability of species composition and importance between Sites 1 and 2 , the hypothesis is supported. The stability seen here is not unusual on barrier islands. For example, SNYDER and Boss (2002) showed that from 1996 through 1998, species similarity on an undisturbed transect across Santa Rosa Island, Florida, ranged from 87.6 to $91.4 \%$, and mean percent cover ranged from 26.4 to $32.5 \%$. EHRENFELD (1990) noted that when physiographic conditions on barrier islands are stable, especially with respect to distance from the ocean and elevation, vegetation patterns remain more or less stable.

Sand movement on South Padre Island is of considerable practical importance. Sand migration develops drifts on Highway 100, and to prevent migrating dunes from burying 
the roadway, Texas Department of Transportation (TxDOT) is engaged in a constant effort of sand removal and disposal. In 2004 the cost of this effort was $\$ 250,741$, and in 2005 it was $\$ 54,845$ (T. RUBIO, TxDOT, personal communication). In addition, migrating dunes bury vegetation in the path of movement, which exacerbates the problem of unconsolidated sand movement. Many of the devegetated areas on South Padre Island are located within a short distance of the Laguna Madre, and transported sand can cover sea grass beds, which form the base of food webs in the lagoon. Rather than removing sand from unwanted places such as Highway 100, it may be a better solution to spend monies on stabilizing dunes with vegetation. This study suggests that replanting does not have to be extensive to significantly reduce sand transport.

\section{CONCLUSIONS}

Elevation change occurred in all sites and topographic zones studied. Even sites where mean percent vegetative cover was as great as $65.1 \%$ had a total elevation change (sum of loss and gain) of $15.6 \mathrm{~cm}$ over the course of a year. Sites where vegetation was absent had a total elevation change 4.6 times greater $($ mean $=71.9 \mathrm{~cm})$. Elevation change was no greater where vegetative cover was $12.5 \%$ than it was where vegetative cover was $\mathbf{5 7 \%}$. This finding is similar to results from wind tunnel experiments. The hypothesis that there should be an inverse correlation between elevation change and percent cover was confirmed when all sites and transects were combined, but the relationship was relatively weak, and it did not hold at all sites and topographic zones when these were considered separately. One of three sites showed a significant change in percent cover over the course of a year. At two sites where there was sufficient vegetation for a significant loss in cover to be recognized, the stability of percent cover, species composition, and species importance were greater where elevation change was less.

These findings suggest that individuals working to revegetate dunes to stabilize them do not have to achieve extensive cover to have a significant effect. Relatively sparse cover of 12 to $17 \%$ may be sufficient to significantly reduce sand transport. Thus, costs may be less, or a much larger area may be replanted for the same cost.

\section{ACKNOWLEDGMENTS}

We are grateful to the National Oceanic and Atmospheric Administration, the Coastal Coordination Council of the Texas General Land Office, and The University of Texas-Pan American for financial support. We thank Mr. Frank Houzvicka, Western Data Systems, Inc., San Antonio, Texas, for technical assistance.

\section{LITERATURE CITED}

BUCKLEY, R., 1987. The effect of sparse vegetation cover on the transport of dune sand by wind. Nature, 325(6103), 426-428.
CANFIELD, R.H., 1941. Application of the line interception method in sampling range vegetation. Journal of Forestry, 39(4), 388-394.

DAHL, B.E.; FALL, B.A.; LoHSE, A., and APPAN, S.G., 1974. Stabilization and Reconstruction of Texas Foredunes with Vegetation. Gulf Universities Research Consortium 139, pp. 1-325.

EHRENFELD, J.G., 1990. Dynamics and processes of barrier island vegetation. Reviews in Aquatic Sciences, 2(3\&4), 437-480.

JUDD, F.W. and LONARD, R.I., 1987. Disturbance and community development. In: Proceedings of the 5th International Symposium on Coastal and Ocean Management, Coastal Zone '87, American Society of Civil Engineers (Seattle, Washington), pp. 1731-1745.

JUDD, F.W.; LONARD, R.I., and SidES, S.L., 1977. The vegetation of South Padre Island, Texas in relation to topography. Southwestern Naturalist, 22(1), 31-48.

JuDD, F.W.; LonARD, R.I.; EveritT, J.H., and VillarReal, R., 1989. Effects of vehicular traffic in the secondary dunes and vegetated flats of South Padre Island, Texas. In: Proceedings of the 6th International Symposium on Coastal and Ocean Management, Coastal Zone '89, American Society of Civil Engineers (Charleston, South Carolina), pp. 4634-4645.

JuDD, F.W. and SIDES, S.L., 1983. The effect of Hurricane Allen on the near-shore vegetation of South Padre Island. Southwestern Naturalist, 28(3), 365-369.

LONARD, R.I. and JuDD, F.W., 1980. Phytogeography of South Padre Island, Texas. Southwestern Naturalist, 25(3), 313-322.

LONARD, R.I. and JUDD, F.W., 1997. The biological flora of coastal dunes and wetlands. Sesuvium portulacastrum (L.)L. Journal of Coastal Research, 13(1), 96-104.

LONARD, R.I.; JuDD, F.W.; EvERITT, J.H.; Escobar, D.E.; AlanIZ, M.A.; Cavazos III, I., and Davis, M.R., 1999. Vegetative change on South Padre Island, Texas, over twenty years and evaluation of multispectral videography in determining vegetative cover and species identity. Southwestern Naturalist, 44(3), 261-271.

LONARD, R.I.; JuDD, F.W.; EverITT, J.H.; EscoBAR, D.E., and DAvIS, R., 1991. Roadside associated disturbance on coastal dunes. In: Proceedings of the 7th International Symposium on Coastal and Ocean Management, Coastal Zone '91, American Society of Civil Engineers (Long Beach, California), pp. 2823-2836.

LONARD, R.I.; JUDD, F.W., and SiDES, S.L., 1978. Annotated checklist of the flowering plants of South Padre Island, Texas. Southwestern Naturalist, 23(3), 497-510.

NorDstrom, K.F.; JACKSON, N.L.; KLEIN, A.H.L.F.; ShermaN, D.J., and HESP, P.A., 2006. Offshore aeolian transport across a low foredune on a developed barrier island. Journal of Coastal Research, 22(5), 1260-1267.

Oosting, H.J. and Billings, W.B., 1942. Factors effecting vegetational zonation on coastal dunes. Ecology, 23(2), 131-142.

SARRE, R.D., 1989. Aeolian sand drift from the intertidal zone on a temperate beach: potential and actual rates. Earth Surface Processes and Landforms, 14, 247-258.

SNYDER, R.A. and Boss, C.L., 2002. Recovery and stability in barrier island plant communities. Journal of Coastal Research, 18(3), 530536.

Stalter, R., 1993. Dry coastal ecosystems of the Gulf Coast of the United States of America. In: VAN DER MAAREL, E. (ed.), Dry Coastal Ecosystems: Africa, America, Asia and Oceania. New York, New York: Elsevier, pp. 375-387.

WAlker, I.J.; HeSP, P.A.; DAVIDSON-ARnOtT, R.G.D., and OlleHEAD, J., 2006. Topographic steering of alongshore airflow over a vegetated foredune: Greenwich Dunes, Prince Edward Island, Canada. Journal of Coastal Research, 22(5), 1278-1291.

Weise, B.R. and White, W.A., 1980. Padre Island National Seashore: A Guide to the Geology, Natural Environments, and History of a Texas Barrier Island. Austin, Texas: Bureau of Economic Geology, The University of Texas at Austin, 94p. 